\title{
Characteristics and yield of slaughter of dairy calves receiving cheese whey and colostrum in a liquid diet
}

\section{Características e rendimento do abate de bezerros leiteiros recebendo soro de leite e colostro em dieta líquida}

\author{
Renata Nayhara de Lima ${ }^{1 *}$; Andrezza Kyarelle Bezerra de Moura ${ }^{2}$; Ana Paula \\ Pinheiro de Assis ${ }^{3}$; Hélia Maria de Souza Leite ${ }^{3}$; Francisca Cedma de Sousa \\ Oliveira $^{3}$; Fabrício Xavier Morais ${ }^{3}$; Jéssica Berly Moreira Marinho; Liz Carolina \\ da Silva Lagos Cortes Assis ${ }^{4}$; Patrícia de Oliveira Lima ${ }^{4}$
}

\section{Highlights:}

O consumo da dieta não foi afetado pelo uso do sucedâneo.

O rendimento da carcaça foi satisfatório com o uso do soro de queijo.

Componentes não carcaça usados na fabricação de embutidos.

\begin{abstract}
The objective of this study was to evaluate the effects of suckling with cheese and colostrum, from whole milk, on the characteristics and yields of slaughter of dairy calves at 60 days. Twenty-four uncastrated male Hosltein calves were used. The experimental treatments included: integral milk (MI); 50\% integral milk $+50 \%$ in natura whey cheese (MW); and $30 \%$ colostrum $+70 \%$ whey cheese $(\mathrm{CW})$. Dry matter intake of concentrate (IDMC) and hay (IDMH), mean daily gain (MDG), and total weight gain (WGT) were evaluated. In addition, weights and yields of hot and cold carcasses, loss and breaking during cooling, and length and thoracic depth of the carcass, commercial cuts, and non-carcass components were measured. Resultantly, a significant effect $(\mathrm{P}<0.05)$ was observed for IDMC, live weight at slaughter, warm carcass weight, cold carcass weight, and carcass length; here, MW and CS treatment differed from LS. Thus, these substitute diets to whole milk showed no interference with physiological and biometric patterns in the animals.
\end{abstract}

Key words: Lactation. Carcass. Performance of calves. Substitute.

\section{Resumo}

Objetivou-se avaliar a influência do aleitamento com soro de queijo e colostro sobre o leite integral às características e rendimentos de abate de bezerros de origem leiteira aos 60 dias. Foram utilizados 24 bezerros machos não castrados, mestiços da raça holandesa. Os tratamentos experimentais foram:

${ }^{1}$ Prof $^{a}$ Dra $^{\mathrm{a}}$, Instituto Federal de Educação, Ciência e Tecnologia do Rio Grande do Norte, IFRN, Ipanguaçu, RN, Brasil. E-mail: renata.nayhara@gmail.com

2 Prof $^{a}$ M.e, Instituto Federal de Educação, Ciência e Tecnologia do Pará, IFPA, Breves, PA, Brasil. E-mail: andrezza_kyarelle@ hotmail.com

3 Discentes, Universidade Federal Rural do Semi-Árido, UFERSA, Mossoró, RN, Brasil. E-mail: pinheiropaula87@hotmail.com; heliazootecnista@hotmail.com; cedma_oliveira@hotmail.com; fabriciomorais-z@hotmail.com; jessicaberlymm@gmail.com

4 Prof $^{\text {as }}$ Dras $^{\text {as }}$ Universidade Federal Rural do Semiárido, UFERSA, Mossoró, RN, Brasil. E-mail: liz@ufersa.edu.br; pattlima@ ufersa.edu.br

*Author for correspondence 
Leite Integral (LI); $50 \%$ Leite integral $+50 \%$ de Soro de queijo in natura (LS); $30 \%$ Colostro $+70 \%$ de Soro de queijo (CS).Foram realizadas avaliações de consumo de matéria seca do concentrado (CMSC) e do feno (CMSF) e ganho médio diário (GMD) e ganho de peso total (GPT), além da avaliação de pesos e rendimentos da carcaça quente e carcaça fria, perda e quebra ao resfriamento, comprimento e profundidade torácica da carcaça, além dos pesos dos cortes comerciais e componentes não-carcaça. Foi observado efeito significativo $(\mathrm{P}<0,05)$ para as variáveis $\mathrm{CMSC}$, peso vivo ao abate, peso da carcaça quente, peso da carcaça fria e comprimento de carcaça onde o tratamento LI e CS diferiram do LS. As dietas substitutivas ao leite integral não diferiram e não apresentaram interferências aos padrões fisiológicos e biométricos nos animais.

Palavras-chave: Aleitamento. Carcaça. Desempenho de bezerros. Sucedâneo.

\section{Introduction}

To maximize milk production at dairies, at present, most male calves are not used for meat production because they need to ingest large amounts of milk in the early stages of their development (L. H. C. Santos, Carvalho, Bianchi \& Piedade, 2016). Therefore, in order for it to be viable to use dairy males for meat production, a specific brood system should be adopted to reduce the costs of these animals.

Boito et al. (2015) evaluated the suckling of male calves with a replacement milk and obtained compensatory gains upon using $66 \%$ of replacer in liquid diet. According to Teixeira, Oliveira, Sousa and Silva (2007), to reduce the cost of replacing natural suckling, the acceptable performance of calves must be at least $20 \%$ lower than calves fed whole milk. According to Viégas et al. (2017), one of the strategies to reduce the cost of natural suckling in the milk production system is to anticipate the age to wean, reduce the amount of milk supplied, and substitute whole milk with a replacement that is able to provide adequate nourishment. Some alternatives to whole milk that have potential nutritional value include the by-products of the dairy industry.

Among whole milk substitutes, cheese whey, a dairy byproduct of cheese processing, has been used as a substitute. Research has shown that it can be used to raise lambs, reducing production costs and the release of pollutant residues into the environment as well as increasing the profitability of substituting up to $45 \%$ of whole milk (R. G. Costa et al., 2010).
Lima et al. (2011) observed similar development among calves receiving cheese whey, compared with animals receiving whole milk, when weaned at 60 days of age. Colostrum can also be used for calf feeding and is an appropriate and viable source for calf feeding. Moreover, it has nutritional and immunological characteristics superior to milk and the advantage of not considerably affectingthe producer's recipe (Saalfeld et al., 2013).

Thus, the objective of this study was to evaluate the effects of feeding with cheese or colostrum whey on the meat characteristics and slaughter yields of dairy calves.

\section{Material and Methods}

The experiment was carried out at the Federal Rural University of the Semi-arid Region, located in the city of Mossoró-RN, Brazil, in the Institution's Bovine Industry, located at $05^{\circ} 11$ ' 15 " $\mathrm{S}$ and $37^{\circ} 20^{\prime} 39^{\prime \prime} \mathrm{W}$, at $16 \mathrm{~m}$ altitude. The climate of the region, according to the Köppen classification, is BSwh: dry and very hot.

Twenty-four uncastrated male Holstein x Zebu cross calveswere used. The animals were acquired from dairy properties in the region. They were $5 \pm 3$ days of age and had an initial average weight of 33 $\mathrm{kg}$. The calves were confined to individual mason pens of about $12 \mathrm{~m}^{2}$, with access to commercial calf concentrate for calves (94.78\% DM and 18.98\% CP) and Tifton hay (Cynodon sp.;94.64\% DM and $7.33 \% \mathrm{CP}$ ) from acquisition to weaning at 60 days. 
The treatments studied in this experiment were related to the supply of liquid food, they included: whole milk (WM); 50\% whole milk $+50 \%$ fresh cheese whey (MW); and 70\% fresh cheese whey $+30 \%$ colostrum (WC). Fresh cheese whey and whole milk were purchased at a dairy and stored in a freezer for cooling for a maximum of 1.5 days. The colostrum used was acquired throughout the experiment from a private farm in the region and stored under freezing. Before delivery, the colostrum was thawed in a water bath until the temperature was near $37^{\circ} \mathrm{C}$ and subsequently supplied.

From birth to 3 days of life, all calves received full colostrum, and from the 4th to 10th day of life, they received 4 liters of whole milk divided equally into 2 supplies (morning and afternoon), according to the management adopted in the farm that provided the colostrum.

From the 10th day, the animals were introduced to the experimental diets for 10 days. Whole milk was gradually replaced, with the introduction of $10 \%$ of the new diet each day, so that changing the diet had less impact on the digestive process. From birth to the diet introduction phase, the animals were managed, such that, at 20 days of age, all animals were receiving their respective experimental diets. In the same period, all animals were dewormed and received injectable ADE vitamin complex $(1 \mathrm{ml} / 50$ $\mathrm{kg}$ ), as indicated by the manufacturer.

The dry matter intake of the hay and concentrate were evaluated by the supply/surplus method, and the amount supplied was adjusted to guarantee $10 \%$ of surplus, compared to the previous day's intake. Weekly experimental weights were measured, always in the morning before the liquid diet was supplied, to record the weight gain.

At 60 days of age, the calves were weighed and fasted for approximately 16 hours during the night, with access only to water. The next morning, they were weighed, to obtain the slaughter weight (PA), and taken to the slaughterhouse under the supervision of the Municipal Inspection Service. In the slaughter room they were numbed, bled and then skinned. The carcasses and offal were separated, prepared and weighed.

Empty body weight (EBW) was measured using the sum of the weights of paws, head, skin, reproductive tract, blood, organs, empty viscera, internal fat, and carcass. The carcasses were also weighed to obtain the hot carcass weight $(\mathrm{HCW})$ and hot carcass yield in relation to the empty body weight $(\mathrm{HCY}=\mathrm{HCW} / \mathrm{EBW} \times 100)$ using the slaughterhouse scale. Simultaneously, measurements of the $\mathrm{pH}$ and temperature of the hot carcass were performed using a portable digital potentiometer and digital infrared thermometer, respectively, in an incision in the longissimus dorsi muscle region at the 12th and 13th ribs. After weighing and measuring, half-carcasses were identified, hung by the tarsometatarsal joint on appropriate hooks, and cooled for 24 hours at temperatures of 2 to $5{ }^{\circ} \mathrm{C}$ in the slaughterhouse's own refrigeration chamber.

In cold half-carcasses, cold carcass weighing (CCW) was conducted and cold carcass yield in relation to empty body weight $(\mathrm{CCY}=\mathrm{CCW} / \mathrm{EBW}$ $\times 100)$ as well as cold carcass temperature and $\mathrm{pH}$ was calculated. The left half carcasses were used to measure carcass length (CL), from occipital bone to the curvature of the pubic bone (height of the 1st coccygeal vertebra), and thorax depth (TD), i.e., the maximum distance between the outside and the back of the carcass. Body compactness index (BCI) was obtained following the methodology of $\mathrm{G}$. S.Costa et al. (2006), in which, body compactness index (BCI) was obtained using the relationship between the live weight $(\mathrm{kg})$ and the body length $(\mathrm{cm})$ of the animal. The following variables were also evaluated: cooling weight loss $(\mathrm{CW})$, i.e., the difference $(\mathrm{kg})$ between the hot carcass weight and the cold carcass weight, and cooling break (CB), i.e., the percentage difference in hot carcass weight and cold carcass weight in relation to hot carcass weight. 
The left half carcass was then cut by removing the neck, the palettes, ribs and legs (right and left), the fillets, the loin, and the tail. Then, boning was done resulting in the following commercial cuts: fillet, boneless palette, soft coxão, hard coxão, duckling, rump steak, complete rump (rump + breast), loin, ossobuco (front and rear), neck, ribs, tail (oxtail), and empty (skirt steak), following the methodology suggested by Pardi (1993). The commercial cuts were weighed and recorded as were the total fat and bones resulting from the cuts. The relative weights of commercial cuts (\%) were obtained in relation to the cold carcass weight.

The experimental design was completely randomized, with three treatments and eight replications. Data were subjected to analysis of variance using the F-test, and parameters with a significant effect on the diet were compared by Tukey test at $5 \%$ probability using the SAS software (STATISTICAL ANALYSIS SYSTEM INSTITUTE [SAS], 2004).

Due to the multicollinearity between the studied measures, multiple linear regression was performed using the SAS REG procedure and the STEPWISE model to determine the equation that could best predict the live slaughter weight (LSW), hot carcass weight ( $\mathrm{HCW})$, cold carcass weight (CCW), and hot carcass yield (HCY) of calves using body biometric measurements.

\section{Results and Discussion}

No difference $(\mathrm{P}>0.05)$ was observed between treatments for hay dry matter intake, daily average gain and total weight gain (Table 1). However, a tendency towards higher concentrate dry matter intake was observed in animals receiving MW compared to calves receiving the control treatment (MI) $(\mathrm{P}=0.09)$, but not for animals fed CW (P> $0,05)$. In the study by Boito et al. (2015), as milk substitution occurred, the concentrate dry matter intake increased, which is related to the quality of the substitute when compared to milk, promoting higher concentrate consumption to meet nutritional requirements. This corroborates the observations of this study, in which there was a need for nutritional compensation of calves due to the lower energy intake of the liquid diet based on MW compared to MI. For calves fed CW, there was less interference of concentrate intake when the animals had colostrum in the composition of their diet, probably due to colostrum being rich in nutrients whereas MW and MI didn't include colostrum.

\section{Table 1}

Concentrate dry matter intake (CDMI), hay dry matter intake (HDMI), average daily gain (AVG), total weight gain (TWG), effect (P) and coefficient of variation (CV) of calves receiving different liquid diets

\begin{tabular}{|c|c|c|c|c|c|}
\hline \multirow{2}{*}{ Variable } & \multicolumn{3}{|c|}{ Liquid Diets } & \multirow{2}{*}{$\mathrm{P}$} & \multirow{2}{*}{$\mathrm{CV}(\%)$} \\
\hline & $\mathrm{MI}^{(1)}$ & $\mathrm{MW}^{(2)}$ & $\mathrm{CW}^{(3)}$ & & \\
\hline CDMI (Kg/dia) & 0,428 & 0,656 & 0,595 & 0,09 & 29,87 \\
\hline HDMI (Kg/dia) & 0,070 & 0,056 & 0,070 & 0,64 & 43,80 \\
\hline $\mathrm{AVG}(\mathrm{Kg})$ & 0,35 & 0,31 & 0,46 & 0,20 & 38,05 \\
\hline TWG (Kg) & 17,27 & 15,32 & 22,48 & 0,20 & 38,10 \\
\hline
\end{tabular}

(a,b) Superscript values with different letters on the same line are different according to Tukey's test. ${ }^{(1)}$ Whole milk. ${ }^{(2)} 50 \%$ Whole milk $+50 \%$ fresh cheese whey. ${ }^{(3)} 70 \%$ Fresh cheese whey $+30 \%$ Colostrum.

The MI substitutes studied were able to promote weight gains of the same magnitude as whole milk, as shown in Table 1. França, Coelho, Carvalho, Martins and Ribeiro (2011), who evaluated the 
performance of calves fed liquid diets, found that calves in the replacement group had a weight gain of 26 to $60 \mathrm{~kg}$. Thus, for the use of different substitutes for MI, the quality and nutritional levels should be evaluated so that they do not compromise the animal's performance or present higher costs than whole milk (Boito et al., 2015).

The parameters related to slaughtering procedures did not show significant differences between treatments $(\mathrm{P}>0.05)$ with pre and postcooling averages of 6.65 and 5.43, respectively, for $\mathrm{pH}$ and $29.4{ }^{\circ} \mathrm{C}$ and $5.76{ }^{\circ} \mathrm{C}$, respectively, for temperature. These results followed expectations, since there were no differences in the weight gain of the animals and the carcasses were submitted to the same slaughtering and refrigeration procedures. In addition, the averages obtained are in accordance with the review by A. C. P. Santos, Silva, Oliveira and Valença (2018), indicating that slaughtering procedures did not generate stressors capable of causing negative effects on carcass $\mathrm{pH}$, and consequently did not affect the quality of the meat.

There was no effect of liquid diets $(\mathrm{P}>0.05)$ on pre-slaughter live weight. However, animals from the MW treatment showed a tendency to having a lower post-fast slaughter weight $(\mathrm{P}=0.08)$ compared to animals receiving colostrum in their liquid diet, which resulted in a lower hot and cold carcass weight ( $\mathrm{P}=0.06$ and $\mathrm{P}=0.07$, respectively) and shorter carcass length $(\mathrm{P}=0.07)$ for LS treatment (Table 2). This trend corroborates with F. N. Vaz, Lobato and Pascal (2011) who stated that the quantitative characteristics of cattle carcasses can be affected mainly by the slaughter weight of the animals. It should also be noted that the animal's weight, when taken as an isolated measure, may overestimate or underestimate the actual composition of carcass tissues, depending on the type of diet used (Silva et al. 2016).

Table 2

Slaughter yields, coefficient of variation $(\mathrm{CV})$ and effect $(\mathrm{P})$ of calves as a function of different liquid diets

\begin{tabular}{|c|c|c|c|c|c|}
\hline \multirow{2}{*}{ Variable } & \multicolumn{3}{|c|}{ Treatments } & \multirow{2}{*}{$\mathrm{P}$} & \multirow{2}{*}{$\mathrm{CV}(\%)$} \\
\hline & $\mathrm{MI}^{(1)}$ & $\mathrm{MW}^{(2)}$ & $\mathrm{CW}^{(3)}$ & & \\
\hline Pre-slaughter live weight $(\mathrm{kg})$ & 52,42 & 45,31 & 56,30 & 0,18 & 18,87 \\
\hline Live slaughter weight (kg) & 51,17 & 44,36 & 56,01 & 0,08 & 17,62 \\
\hline Empty body weight (kg) & 44,72 & 42,60 & 49,35 & 0,30 & 14,30 \\
\hline Gastrointestinal Content (kg) & 5,66 & 6,22 & 6,59 & 0,69 & 32,69 \\
\hline Hot Carcass Weight (kg) & 26,90 & 22,62 & 29,04 & 0,07 & 18,95 \\
\hline Cold Carcass Weight (kg) & 25,92 & 21,94 & 28,38 & 0,06 & 18,73 \\
\hline Hot carcass yield (\%) & 59,04 & 57,22 & 58,57 & 0,39 & 3,55 \\
\hline Cold Carcass Yield (\%) & 56,94 & 55,01 & 57,28 & 0,23 & 3,57 \\
\hline Loss on cooling (kg) & 0,90 & 0,86 & 0,66 & 0,30 & 32,11 \\
\hline Cooling Break (\%) & 3,63 & 2,95 & 2,18 & 0,11 & 38,27 \\
\hline Carcass length $(\mathrm{cm})$ & 106,25 & 97,36 & 106,00 & 0,07 & 7,78 \\
\hline Chest Depth $(\mathrm{cm})$ & 39,07 & 38,44 & 39,60 & 0,60 & 5,24 \\
\hline
\end{tabular}

(a,b) Superscript values with different letters on the same line are different according to Tukey's test. (1) Whole milk. ${ }^{(2)} 50 \%$ Whole milk $+50 \%$ fresh cheese whey. ${ }^{(3)} 70 \%$ Fresh cheese whey $+30 \%$ Colostrum. 
The weight of gastrointestinal contents, carcass yields, and variables related to cooling losses did not differ according to the tested diets $(\mathrm{P}>0.05)$ (Table 3). Ribeiro et al. (2001), when slaughtering calves approximately 75 days old and with an average weight of $76 \mathrm{~kg} \mathrm{LW}$, found a mean cold carcass yield of $56.32 \%$, in agreement with the values found in the present study.

For the variable break in cooling, no significant difference was observed between the diets tested $(\mathrm{P}>0.05)$ (Table 2), with a mean of $2.92 \%$. These values are higher than those found by Dias and
Leite (2013), in a literature review; where, they indicate that values of cooling fall from 0.75 to $2.5 \%$. According to Roça (2011), the breakdown in cooling is mainly regulated by the cover fat that protects the carcass from dehydration. As calves have little deposition of subcutaneous fat, carcass cooling must follow different criteria, such as higher temperatures and protection of carcasses, to those conventionally adopted in Brazil for adult cattle carcasses, to avoid the cold shortening effects of intense cooling (Prado \&Felício, 2010).

Table 3

Absolute weight (kg), relative weight (\%), coefficient of variation (CV) and effect (P) of commercial calf cuts as a function of liquid diet

\begin{tabular}{|c|c|c|c|c|c|c|c|c|c|c|}
\hline \multirow{2}{*}{ Yield } & \multicolumn{3}{|c|}{ Absolute weight $(\mathrm{kg})$} & \multirow{2}{*}{$\mathrm{P}$} & \multirow{2}{*}{$\mathrm{CV}(\%)$} & \multicolumn{3}{|c|}{ Relative weight (\%) } & \multirow{2}{*}{$\mathrm{P}$} & \multirow{2}{*}{$\mathrm{CV}(\%)$} \\
\hline & $\mathrm{MI}^{(1)}$ & $\mathrm{MW}^{(2)}$ & $\mathrm{CW}^{(3)}$ & & & MI & MW & $\mathrm{CW}$ & & \\
\hline Filet & 0,19 & 0,15 & 0,19 & 0,17 & 19,61 & 1,49 & 1,34 & 1,44 & 0,63 & 13,20 \\
\hline Rump & 0,31 & 0,29 & 0,35 & 0,58 & 24,58 & 2,48 & 2,45 & 2,56 & 0,90 & 10,12 \\
\hline Titty & 0,09 & 0,08 & 0,09 & 0,77 & 29,22 & 0,76 & 0,73 & 0,65 & 0,58 & 18,69 \\
\hline Filet Steak & 0,18 & 0,16 & 0,16 & 0,59 & 26,54 & 1,46 & 1,38 & 1,17 & 0,38 & 19,20 \\
\hline Soft Thigh & 0,77 & 0,72 & 0,86 & 0,59 & 24,56 & 5,76 & 5,61 & 5,70 & 0,80 & 9,32 \\
\hline Hard Thigh & 0,74 & 0,65 & 0,76 & 0,59 & 21,62 & 6,13 & 6,19 & 6,37 & 0,09 & 8,61 \\
\hline Duckling & 0,55 & 0,51 & 0,60 & 0,76 & 25,47 & 4,36 & 4,41 & 4,40 & 0,76 & 9,27 \\
\hline Loin & 0,80 & 0,59 & 0,83 & 0,10 & 26,33 & 6,14 & 5,04 & 5,79 & 0,15 & 15,90 \\
\hline Palette & 1,23 & 1,14 & 1,45 & 0,15 & 22,31 & 9,75 & 9,76 & 10,74 & 0,21 & 11,79 \\
\hline Front Ossobuco & 0,74 & 0,63 & 0,70 & 0,39 & 15,01 & 5,75 & 5,51 & 5,34 & 0,66 & 8,18 \\
\hline Back Ossobuco & 0,93 & 0,84 & 1,01 & 0,14 & 15,21 & 7,64 & 7,34 & 7,12 & 0,37 & 7,17 \\
\hline Neck & 1,16 & 0,81 & 1,23 & 0,20 & 30,74 & 9,10 & 7,42 & 8,53 & 0,72 & 30,43 \\
\hline Rib & 2,74 & 2,57 & 2,74 & 0,11 & 16,03 & 22,02 & 22,80 & 20,14 & 0,54 & 16,11 \\
\hline Tail & 0,17 & 0,14 & 0,19 & 0,14 & 24,14 & 1,62 & 1,08 & 1,56 & 0,16 & 33,43 \\
\hline Skirt steak & 0,36 & 0,35 & 0,40 & 0,90 & 29,09 & 2,84 & 3,01 & 2,90 & 0,14 & 13,42 \\
\hline
\end{tabular}

(1) Whole milk. ${ }^{(2)} 50 \%$ Whole milk $+50 \%$ fresh cheese whey. ${ }^{(3)} 70 \%$ Fresh cheese whey $+30 \%$ Colostrum.

During the evaluation of the commercial cuts (Table 3), no significant difference $(\mathrm{P}>0.05)$ was observed between the tested liquid diets. Müller (1987) states that measurement characteristics and carcass yields are parameters that have a high correlation with the usable portion of the muscle tissue of the animals. Thus, the study of these characteristics allows comparison of supplement feeding systems with traditional systems based on whole milk. Thus, the partial replacement of whole milk by cheese whey or the association of cheese whey with colostrum is as efficient a 
nutritional source for calves as the use of whole milk, as demonstrated by the characteristics of the commercial cuts studied.

The liquid diets tested had no effect $(\mathrm{P}>0.05)$ on the weight and yield of non-carcass components of calves (Table 4), despite the fact that the organs linked to digestion and metabolism, such as the liver and intestine, are affected by diet and the weight gain of animals (Moreno et al., 2011; Almeida et al., 2011). Therefore, the evaluation of these components should be considered, as carcass yield is directly influenced by the development of internal organs and other body weight components. Moreover, it is also influenced by genetic group, sexual condition, and feeding system and is used for income generation through wholesale or value addition with sausage manufacturing (Carvalho, Brochier, Pivato, Teixeira \& Kieling, 2007).
R. Z. Vaz et al. (2015) state that, by analyzing the revenues obtained with non-carcass components, they showed that leather and blood, followed by the liver, are the most important items of industrial revenue, accounting for $58 \%$ of the value obtained from non-carcass components. If these are added, the sum of head meat, bleed, and industrial meat now account for more than $2 / 3$ of the non-carcass component's industrial revenue. In the present study, this set represented, on average, approximately $55 \%$ of the empty body weight of these animals or $30 \%$ as a function of live weight, regardless of the liquid diet adopted. These values are considered acceptable due to the age at which the animals were slaughtered, because the younger the animal the greater the influence of non-carcass components on carcass yield.

Table 4

Absolute weight (kg), relative weight (\%), coefficient of variation $(\mathrm{CV})$ and effect $(\mathrm{P})$ of non-carcass components of calves as a function of different liquid diets

\begin{tabular}{|c|c|c|c|c|c|c|c|c|c|c|}
\hline \multirow{2}{*}{ Yield (kg) } & \multicolumn{3}{|c|}{ Absolute weight (kg) } & \multirow{2}{*}{$\mathrm{P}$} & \multirow{2}{*}{$\begin{array}{l}\mathrm{CV} \\
(\%)\end{array}$} & \multicolumn{3}{|c|}{ Relative weight (\%) } & \multirow{2}{*}{$P$} & \multirow{2}{*}{$\begin{array}{l}\mathrm{CV} \\
(\%)\end{array}$} \\
\hline & $\mathrm{MI}^{(1)}$ & $\mathrm{MW}^{(2)}$ & $\mathrm{CW}^{(3)}$ & & & MI & MW & $\mathrm{CW}$ & & \\
\hline Leather & 3,28 & 3,05 & 3,67 & 0,17 & 15,31 & 7,28 & 6,99 & 7,84 & 0,30 & 10,99 \\
\hline Head & 3,76 & 3,48 & 3,91 & 0,14 & 10,40 & 8,35 & 8,62 & 7,99 & 0,33 & 7,41 \\
\hline Paws & 2,28 & 2,01 & 2,31 & 0,10 & 12,55 & 5,14 & 4,91 & 4,71 & 0,35 & 9,72 \\
\hline Penis & 0,05 & 0,05 & 0,06 & 0,81 & 27,13 & 0,12 & 0,20 & 0,17 & 0,29 & 43,44 \\
\hline Blood & 2,19 & 1,94 & 2,01 & 0,62 & 20,55 & 4,93 & 4,61 & 4,14 & 0,36 & 19,52 \\
\hline Kidney & 0,38 & 0,36 & 0,43 & 0,35 & 21,91 & 0,83 & 0,88 & 0,88 & 0,78 & 16,04 \\
\hline Lungs & 0,74 & 0,70 & 0,73 & 0,85 & 17,66 & 1,65 & 1,80 & 1,47 & 0,48 & 24,68 \\
\hline Spleen & 0,31 & 0,16 & 0,21 & 0,27 & 64,68 & 0,55 & 0,34 & 0,46 & 0,47 & 50,89 \\
\hline Heart & 0,34 & 0,34 & 0,37 & 0,48 & 11,67 & 0,78 & 0,78 & 0,75 & 0,86 & 9,86 \\
\hline Liver & 1,01 & 0,96 & 1,18 & 0,35 & 25,58 & 2,17 & 2,48 & 2,40 & 0,45 & 17,91 \\
\hline Esophagus / Trachea & 0,32 & 0,38 & 0,47 & 0,06 & 27,63 & 0,69 & 0,93 & 0,95 & 0,06 & 22,92 \\
\hline Diaphragm & 0,18 & 0,17 & 0,21 & 0,33 & 27,54 & 0,39 & 0,45 & 0,42 & 0,60 & 23,23 \\
\hline Rumen / Reticulum & 0,79 & 0,71 & 1,03 & 0,08 & 27,32 & 1,56 & 2,16 & 2,09 & 0,06 & 22,40 \\
\hline Omaso & 0,21 & 0,24 & 0,27 & 0,37 & 31,58 & 0,44 & 0,57 & 0,55 & 0,28 & 27,98 \\
\hline Abomaso & 0,35 & 0,32 & 0,35 & 0,79 & 26,39 & 0,76 & 0,90 & 0,72 & 0,26 & 21,27 \\
\hline Small intestine & 1,71 & 1,39 & 1,87 & 0,15 & 26,77 & 3,63 & 3,67 & 3,80 & 0,91 & 18,44 \\
\hline Large intestine & 0,74 & 0,84 & 0,93 & 0,06 & 15,30 & 1,59 & 1,87 & 1,91 & 0,05 & 12,34 \\
\hline
\end{tabular}

(1) Whole milk. (2) $50 \%$ Whole milk $+50 \%$ fresh cheese whey. ${ }^{(3)} 70 \%$ Fresh cheese whey $+30 \%$ Colostrum. 
When using fermented colostrum in the liquid diet of calves, Castro, Campos, Mâncio and Cecon (2004)observed that the animals had higher rumenreticulum weight than those who received whole milk. These authors attributed this result to the higher concentrate intake observed in animals receiving the substitute diet that was capable of accelerating the rumen transformation process. In the present study, even though there was higher concentrate intake for MW, rumen-reticulum weight did not differ between the different liquid diets. According to a review by Caetano, Caetano and Oliveira (2016), the expansion of this organ occurs due to the amount of milk supplied to animals and/ or the age of slaughter, after 56 days of life.

Biometric and morphometric studies, in addition to weight, also take into consideration the type of diet used, due to the dietary effect on organ morphology and physiology. In the present experiment, besides the rumen reticulum, the development of the other organs of the gastrointestinal tract (omaso, abomasum, large intestine, and small intestine) were not influenced by liquid diets, probably due to the age of slaughter at 60 days. In the multiple regression analysis using the biometric variables, among the statistically significant equations, using the coefficient of determination, we selected those that presented higher precision to estimate the observed data. We also considered biological application.

Considering the coefficient of determination, it was observed in the prediction equations that LSW should increase $0.71 \mathrm{~kg}$ for each centimeter increase in body length (BL) (Table 5). For HCW an increase $0.46 \mathrm{~kg}$ and $0.68 \mathrm{~kg}$ for each centimeter of TP and WC was predicted, as well as an increase in the muscle to fat ratio for each unit of body compactness index (BCI). For the $\mathrm{CCW}$ an increase of $0.08 \mathrm{~kg}$ and $0.54 \mathrm{~kg}$ was predicted and it was predicted that the CCY should increase $0.09 \mathrm{~kg}$ and $0.50 \mathrm{~kg}$ for each centimeter of TP and WC. This infers that LSW, HCW, CCW, and HCY are highly dependent on TP, BL, and BCI. Pinheiro, Silva, Marques and Yamamoto (2007) state that, although these measurements cannot define carcass characteristics alone, they allow us to predict some important productive characteristics for the study of animal performance, corroborating the data obtained in this experimental trial. Koritiaki, Ribeiro, Fernandes, Souza and Constantino (2012) found that multiple linear regressions almost always presented better coefficients of determination than simple linear regressions, indicating that equations using more than one body measurement are more efficient for estimating live weight than those using only one measurement.

\section{Table 5}

Linear models for prediction of live slaughter weight (LSW), hot carcass weight (HCW), cold carcass weight (CCW), hot carcass yield (HCY), based on multiple regression analysis of biometric measurements and morphometric

\begin{tabular}{cc}
\hline Predictor Equations: & $\mathrm{R}^{2}$ \\
\hline $\mathrm{LSW}=-51,71( \pm 1,98)+0,71( \pm 0,03) \mathrm{BL}+72,57( \pm 1,25) \mathrm{BCI}$ & 0,99 \\
$\mathrm{HCW}=-76,49( \pm 27,60)+0,46( \pm 0,66) \mathrm{TP}+0,68( \pm 0,31) \mathrm{BL}+53,95( \pm 18,82) \mathrm{BCI}$ & 0,93 \\
$\mathrm{CCW}=-42,62( \pm 16,54)+0,08( \pm 0,38) \mathrm{TP}+0,54( \pm 0,18) \mathrm{BL}+29,68( \pm 12,58) \mathrm{BCI}$ & 0,89 \\
$\mathrm{HCY}=-40,61( \pm 15,39)+0,09( \pm 0,36) \mathrm{TP}+0,50( \pm 0,17) \mathrm{BL}+29,23( \pm 11,72) \mathrm{BCI}$ & 0,90 \\
\hline
\end{tabular}

$\mathrm{TP}=$ thoracic perimeter; $\mathrm{BL}=$ body length $\mathrm{BCI}=$ body compactness index . 
The diets tested provided adequate growth of internal organs, similar to that obtained with the use of the control diet (whole milk), thus indicating similar maintenance energy requirements between treatments. That is, higher relative proportions of internal organs and viscera, determine greater maintenance requirement on the part of these, since these components demand higher energy expenditure for maintenance than the rest of the body.

\section{Conclusion}

The diets tested did not negatively affect the carcass characteristics and non-carcass components of calves slaughtered at 60 days, making it possible to replace whole milk with diets based on cheese and colostrum whey without harming the physiological development of these animals. From these in vivo measurements, it is possible to accurately predict, using equation, the weights and carcass yields of Holstein and Zebu crossbred calves.

\section{Acknowledgment}

We thank Banco do Nordeste for financial support.

\section{Ethics Committee Approval}

The experiment was conducted according to ethical standards and approved by the Animal Experimentation Ethics Committee of the Federal RuralUniversity of the Semi-aridRegion(UFERSA), opinion no. 17/2011 / case 23091.002083 / 2011-66 - CEUA/ UFERSA.

\section{References}

Almeida, T. R. V., Perez, J. R. O., Chlad, M., França, P. M., Leite, R. F. \&Nolli, C. P. (2011). Desempenho e tamanho de vísceras de cordeiros Santa Inês após ganho compensatório. Revista Brasileira de Zootecnia, 40(3), 616-621. doi: 10.1590/S151635982011000300021
Boito, B., Menezes, L., Ziech, M., Kuss, F., Lisbinski, E., \&Fiorelli, A. (2015). Uso de sucedâneo em substituição ao leite no desempenho de bezerros da raça holandesa durante a cria e recria. Ciência Animal Brasileira, 16(4), 498-507. doi: 10.1590/10896891v16i432297

Caetano, M. B., Jr., Caetano, G. A. O. \& Oliveira, M. D. (2016). A influência da dieta no desenvolvimento ruminal de bezerros. Nutritime Revista Eletrônica, 13(6), 4902-4918. Recuperado de https://www. nutritime.com.br/arquivos_internos/artigos/ Artigo_8.pdf

Carvalho, S., Brochier, M. A., Pivato, J., Teixeira, R. C., \& Kieling, R. (2007). Ganho de peso, características da carcaça e componentes não-carcaça de cordeiros da raça texel terminados em diferentes sistemas alimentares. Ciência Rural, 37(3), 821-827. doi: $10.1590 / \mathrm{S} 0103-84782007000300034$

Castro, A. L. M., Campos, W. E., Mancio, A. B., \& Cecon, P. R. (2004). Desempenho e rendimento de carcaça de bezerros alimentados com colostro fermentado, associado ao óleo de soja e zenarol. Arquivo Brasileiro de Medicina Veterinária e Zootecnia, 56(2), 193-201. doi: 10.1590/S010209352004000200009

Costa, G. S. Jr., Campelo, J. E. G., Azevêdo, D. M. M. R., Martins, R., F ${ }^{o}$, Cavalcante, R. R. Lopes, J. B., \& Oliveira, M. E. (2006). Caracterização morfométrica de ovinos da raça Santa Inês criados nas microrregiões de Teresina e campo maior, Piauí. Revista Brasileira de Zootecnia, 35(6), 2260-22676. doi: 10.1590/S1516-35982006000800009

Costa, R. G., Beltrão, E. M., F ${ }^{\circ}$, Medeiros, G. R., Villarroel, A. B. S., Cruz, S. E. S. B. S., \& Santos, E.M. (2010). Substituição do leite de cabra por soro de queijo bovino para cabritos alpinos. Revista Brasileira de Zootecnia, 39(4), 824-830. doi: 10.1590/S1516-35982010000400018

Dias, A. L., \& Leite, P. A. G. (2013). Avaliação da perda de peso em meias-carcaças bovinas submetidas ao sistema de resfriamento por aspersão. Pubvet, 7(23), 2327-2445. Recuperado de http://www.pubvet.com. br/artigo/799/avaliaccedilatildeo-da-perda-de-pesoem-meias-carcaccedilas-bovinas-submetidas-aosistema-de-resfriamento-por-aspersatildeo

França, S. R. A., Coelho, S. G., Carvalho, A. U., Martins, R. G. R., \& Ribeiro, S. L. M. (2011). Desempenho de bezerros alimentados usando sucedâneo até 56 dias de idade. Revista Ceres, 58(6), 790-793. doi: $10.1590 / \mathrm{S} 0034-737 \mathrm{X} 2011000600016$ 
Koritiaki, N. A., Ribeiro, E. L. A., Fernandes, F., Jr., Souza, C. L., \& Constantino, C. (2012). Predição do peso vivo a partir de mensurações corporais em cordeiros Santa Inês. Synergismus Scyentifica UTFPR, 7(1), 1-3. Recuperado de http://revistas. utfpr.edu.br/pb/index.php/SysScy/article/view/1485

Lima, R., Lima, P. O., Cândido, M. D., Silva, T. P. F., Moreira, R. H. F., \& Aquino, R. M. S. (2011). Avaliação econômica de dietas liquidas a base de soro de queijo in natura para bezerros. Revista Brasileira de Saúde e Produção Animal, 12(1), 1421. Recuperado de http://revistas.ufba.br index. php/ rbspa/article/viewArticle/1895

Moreno, G. M. B., Silva, A. G., Sob․, Leão, A. G., Perez, H. L., Loureiro, C. M. B., \& Pereira, G. T. (2011). Rendimento dos componentes não-carcaça de cordeiros alimentados com silagem de milho ou cana-de-açúcar e dois níveis de concentrado. Revista Brasileira de Zootecnia, 40(12), 2878-2885. doi: 10.1590/S1516-35982011001200035

Müller, L. (1987). Normas para avaliação de carcaças e concurso de carcaças de novilhos. Santa Maria: Imprensa Universitária. (Publicação, n.1 dz).

Pardi, M. C. (1993). Ciência, higiene e tecnologia da carne. Goiânia, GO.

Pinheiro, R. S. B., Silva, A. G. S., Marques, C. A. T., \& Yamamoto, S. M. (2007). Biometria in vivo e da carcaça de cordeiros confinados. Archivos de Zootecnia, 56(216), 955-958. Recuperado de http:// www. uco.es/organiza/servicios/publica/az/php/img/ web/06 $17 \quad 39$ 18NotaBiometriaPinheiro.pdf

Prado, C. S., \& Felício, P. E. (2010). Effects of chilling rate and spray-chilling on weight loss and tenderness in beef strip loin. Meat Science, 86(2),430-435. doi: 10.1016/j.meatsci.2010.05.029

Ribeiro, T. R., Pereira, J. C., Oliveira, M. V. M., Queiroz, A. C., Cecon, P. R., Leão, M. I., \& Melo, R. C. A. (2001). Características da carcaça de bezerros holandeses para produção de vitelos recebendo dietas com diferentes níveis de concentrado. Revista Brasileira de Zootecnia, 30(6), 2154-2162. doi: 10.1590/S1516-35982001000800026

Roça, R. O. (2003). Refrigeração. Botucatu: Fazenda Experimental Lageado, FCA.

Saalfeld, M. H., Pereira, D. I. B., Silveira, K. R. K., Schramm, R., Valente, J. S. S., Borchardt, J. L., Gularte, M. A., \& Leite, F. P. L. (2013). Anaerobicallyfermentedcolostrum: analternative for feeding calves. Ciência Rural, 43(9),1636-1641. doi: 10.1590/S0103-84782013000900016

Santos, A. C. P., Silva, B. C. D., Oliveira, V. S., \& Valença, R. L. (2016). Métodos de avaliação de carcaça e de carne dos animais através de predições in vivo e post mortem. Revista Cientifica de Medicina Veterinária, 30, 1-21. Recuperado de http://faef. revista.inf.br/imagens_arquivos/arquivos_destaque/ q1KKIRyuFpO9Eqi_2018-7-10-8-20-18.pdf

Santos, L. H. C., Carvalho, R. C., Bianchi, I. E., \& Piedade, A. R. (2016). Gestão e análise econômica de processo produtivo leiteiro no município de Santo Antônio do Leverger/MT. Revista de Ciências Agroambientais, 14(2), 75-82. Recuperado de https://periodicos.unemat.br/index.php/rcaa/article/ view/1607

SAS (2004). SAS/STAT User's Guide. SAS Institute Inc., Cary, NC, USA.

Silva, N. V., Costa, R. G., Medeiros, G. R., Gonzaga Neto, S., Cezar, M. F., Cavalcanti, M. C. A. (2016). Medidas in vivo e da carcaça e constituintes não carcaça de ovinos alimentados com diferentes níveis do subproduto agroindustrial da goiaba. Revista Brasileira de Saúde e Produção Animal, 17(1), 101115. doi: 10.1590/S1519-99402016000100010

Teixeira, P. A., Oliveira, M. D. S., Sousa, C. C., \& Silva, T. M. (2007). Avaliação de diferentes dietas sobre o desempenho de bezerros da raça holandesa durante o período de aleitamento. Ciência Agrotecnologia, 31(6), 831-837. doi: 10.1590/ S1413-70542007000600034

Vaz, F. N., Restle, J., Pádua, J. T., Fonseca, C. A., Pascoal, L. L., \& Severo, M. M. (2015). Componentes não carcaça de bovinos nelore abatidos com diferentes pesos. Ciência Animal Brasileira, 16(3), 313-323. doi: 10.1590/1089-6891v16i318694

Vaz, R. Z., Lobato, J. F. P., \& Pascoal, L. L. (2011). Desenvolvimento de bezerros de corte desmamados aos 80 ou 152 dias até os 15-16 meses de idade. Revista Brasileira de Zootecnia, 40(1), 221-229. doi: 10.1590/S1516-35982011000100030

Viégas, J., Skonieski, F. R., Weber, A., Pinto-Neto, A., Oliveira, R. L., Ribeiro, C. V. D. M., Bermudes, R. F., \& Nörnberg, M. F. L. (2017). Soro de leite em substituição ao leite na cria de bezerros. Arquivo de Ciências Veterinária e Zoologia da UNIPAR, 20(1), 9-13. doi: 10.25110/arqvet.v20i1.2017.6313 